\title{
DINAMIKA PSIKOLOGIS PENYINTAS PULUNG GANTUNG DI GUNUNG KIDUL
}

\author{
Sulistyo Budiarto, Ryan Sugiarto, \& Flora Grace Putrianti
}

Fakultas Psikologi, Universitas Sarjanawiyata Tamansiswa, Jl. Kusumanegara No. 157, Muja Muju, Kec. Umbulharjo, Yogyakarta 55165, Indonesia

Korespondensi: st.budiarto@ustjogja.ac.id

\section{THE PSYCHOLOGICAL DYNAMIC OF A PULUNG GANTUNG SUICIDE SURVIVOR IN GUNUNG KIDUL}

\begin{abstract}
The high prevalence of suicide rates in Gunung Kidul deserves a scholarly attention, especially through the indigenous perspective. The existence of Pulung Gantung as a cultural myth that endorses suicidal behavior brings about a significant challenge in reducing suicidal rates. The term 'Pulung' is understood as a revelation, a sign or a gift, while the word 'Gantung' means suspension of a person by a ligature around the neck. Hence, Pulung Gantung is understood as a superstitious revelation that is believed to signal an individual to commit suicide. This study aims to identify the psychological factors that influence pulung gantung phenomenon in Gunung Kidul through phenomenological approach to a suicide survivor and his three close relatives. The results demonstrated that suicidal behavior was explained by the weak protective psychological factors, and that suicidal behavior was not performed as a response to Pulung belief; hence it provides insight to the community that suicidal behavior is preventable. This study could potentially inform the government and related parties to promote suicide prevention in the community.
\end{abstract}

Manuscript type: Original Research

\section{Article history:}

Received 17 June 2020

Received in revised form 19 August 2020

Accepted 16 September 2020

Available online 31 October 2020

\section{Keywords:}

Gunung Kidul

Pulung Gantung

suicide

suicide survivor

\begin{abstract}
Abstrak
Prevalensi kasus bunuh diri di Gunung Kidul perlu mendapatkan perhatian yang serius, khususnya dalam perspektif ulayat. Masyarakat masih meyakini mitos Pulung Gantung sebagai penyebab perilaku bunuh diri, yang menjadi tantangan tersendiri dalam upaya pencegahan perilaku bunuh diri. Pulung dimaknai sebagai wahyu, isyarat atau anugerah dan Gantung berarti gantung diri, yang apabila diterjemahkan bermakna wahyu atau isyarat bagi seseorang untuk melakukan bunuh diri. Penelitian ini bertujuan untuk mengidentifikasi faktorfaktor psikologis yang memengaruhi seseorang untuk melakukan perilaku bunuh diri di Gunung Kidul, melalui pendekatan fenomenologi terhadap satu orang penyintas perilaku bunuh diri dan tiga orang dekat penyintas. Hasil menunjukkan adanya faktor psikologis, yaitu lemahnya faktor protektif pada partisipan yang memengaruhi perilaku bunuh diri, sekaligus menunjukan bahwa perilaku bunuh diri bukan disebabkan oleh munculnya Pulung yang tidak dapat dicegah sebagaimana diyakini oleh masyarakat. Secara praktis, temuan ini dapat digunakan sebagai pertimbangan pihak terkait dalam upaya pencegahan perilaku bunuh diri.
\end{abstract}

Kata Kunci: bunuh diri, Gunung Kidul, penyintas bunuh diri, Pulung Gantung

\section{Dampak dan Implikasi dalam Konteks Ulayat}

Salah satu masalah dalam upaya menurunkan angka perilaku bunuh diri di Gunung Kidul adalah masih berkembangnya mitos Pulung Gantung. Masyarakat, terutama golongan tua, mempercayai bahwa Pulung Gantung tidak dapat dihindari. Ini berarti siapapun tidak dapat menghindari atau mencegah Pulung Gantung yang menginspirasi (dianggap sebagai wahyu yang cenderung diartikan positif; dapat berupa bisikan) untuk melakukan bunuh diri. Penelitian ini bertujuan mengungkapkan aspek psikologis dari fenomena Pulung Gantung. Hasil penelitian menunjukkan dinamika aspek psikologis yang mendorong munculnya ide bunuh diri. Artinya, perilaku bunuh diri bukan sebuah Pulung (wangsit) yang tidak dapat dihindari. Upaya pencegahan perilaku bunuh diri sangat mungkin dilakukan dengan memperhatikan faktor-faktor psikologis yang memengaruhi intensi seseorang untuk bunuh diri. 


\section{PENDAHULUAN}

Meskipun bukan fenomena baru, perilaku bunuh diri perlu mendapatkan perhatian serius. Ahmed dkk. (2017) menyebutkan bahwa angka perilaku bunuh diri di seluruh dunia saat ini lebih besar dibandingkan dengan angka kematian yang diakibatkan oleh pembunuhan maupun korban peperangan. World Health Organization [WHO] (2019) mencatat setidaknya 800,000 kematian akibat perilaku bunuh diri di seluruh dunia. Dengan jumlah tersebut, rata-rata terdapat 11 kematian perilaku bunuh diri dari 100,000 jiwa pada tahun 2012. Ini berarti terdapat satu orang yang meninggal karena perilaku bunuh diri setiap 40 detik di seluruh dunia.

Di Indonesia, WHO memperkirakan angka perilaku bunuh diri mencapai 4.3 per 100,000 populasi (Felicitas, 2015). Daerah Istimewa Yogyakarta (DIY) menjadi salah satu daerah dengan angka perilaku bunuh diri tertinggi di Indonesia (Katadata, 2016). Lebih lanjut, daerah yang memiliki perilaku bunuh diri paling tinggi di DIY berasal dari Kabupaten Gunung Kidul.

Wirasto (2012) menyebutkan bahwa angka rata-rata perilaku bunuh diri di Gunung Kidul sebesar 4.48 per 100,000 penduduk. Setidaknya, terdapat 25 kejadian perilaku bunuh diri setiap tahunnya di Gunung Kidul (Lestari \& Budhi, 2017). Lebih lanjut, perilaku bunuh diri tersebut dilakukan dengan gantung diri.

Sejarah mencatat perilaku bunuh diri banyak dipengaruhi oleh latar belakang budaya, keyakinan, kepercayaan agama, dan kehormatan. Di era kejayaan kaum samurai di Jepang, terdapat tradisi seppuku yang merupakan simbol untuk memperoleh kehormatan kembali bagi samurai yang telah gagal. Bagi seorang samurai, kehormatan dan harga diri adalah hal yang penting. Oleh karena itu, mereka lebih baik mati daripada menganggung malu (Wibawarta, 2006). Dalam kepercayaan Hindhu di India, dikenal adat sati yang merupakan perilaku bunuh diri seorang janda untuk mengikuti suami yang telah meninggal terlebih dahulu. Sati atau bakar diri dilakukan perempuan yang ditinggal mati suaminya adalah simbol kesetiaan seorang istri terhadap suaminya (Ardanareswari, 2020). Bunuh diri untuk membela keyakinan dilakukan oleh filsuf besar Socrates. Socrates rela dihukum meminum racun oleh pengadilan Athena daripada harus mengingkari keyakinan pengetahuannya yang telah ia ajarkan kepada anak muda kala itu (Fahrudin, 2012).

\section{Mitos Pulung Gantung sebagai Penyebab Bunuh Diri pada Masyarakat Gunung Kidul}

Masyarakat Gunung Kidul, terutama golongan berusia tua, meyakini perilaku bunuh diri sebagai Pulung Gantung. Kata Pulung berasal dari bahasa Jawa yang bermakna sebuah wahyu, 
isyarat atau anugerah. Sementara itu, kata Gantung berarti bunuh diri dengan cara menggantung diri. Secarah literal, Pulung Gantung dapat diartikan sebagai sebuah wahyu atau isyarat bagi seseorang untuk melakukan perilaku bunuh diri dengan cara gantung diri (Darmaningtyas, 2002). Lebih lanjut, Darmaningtyas (2002) menyebutkan bahwa kehadiran Pulung Gantung ditandai dengan kemunculan bola api berekor bak meteor di tengah malam. Bola api tersebut merupakan sasmita (pertanda) kematian. Apabila salah salah satu rumah menjadi lokasi jatuhnya bola api tersebut, maka penghuni rumah tersebut akan melakukan gantung diri. Keyakinan ini masih dipercayai sampai sekarang, terutama pada kalangan tua.

Pulung Gantung diyakini juga dapat menular kepada orang lain. Arah yang dituju orang yang melakukan Pulung Gantung menjadi isyarat peristiwa berikutnya. Untuk menghentikan hal tersebut, salah satu cara yang sering dilakukan adalah menggali tanah yang berada tepat di bawah lokasi tergantungnya jenazah. Dengan menggali tanah, masyarakat percaya bahwa "wabah" dapat dihentikan peredarannya (Fahrudin, 2012).

Mitos Pulung Gantung cukup menghambat upaya pencegahan perilaku bunuh diri di Gunung Kidul. Darmaningtyas (2002) memiliki kekhawatiran bahwa mitos Pulung Gantung berdampak negatif pada penyelesaian fenomena perilaku bunuh diri di Gunung Kidul. Hal ini karena orang tidak lagi mampu berpikir kritis tentang faktor utama penyebab, melainkan menghindar dan cenderung melakukan penyelesaian dengan cara yang mistis.

Rochmawati (2009) dan Fahrudin (2012) menjelaskan bahwa perilaku bunuh diri di Gunung Kidul sesungguhnya diawali adanya persoalan psikologis dan gangguan mental akibat tidak mendapatkan penanganan yang maksimal, sehingga pada akhirnya seseorang melakukan bunuh diri. Terlebih lagi, faktor depresi menjadi pemicu utama, disusul dengan adanya penyebab sakit fisik yang menahun, persoalan ekonomi, dan keluarga (Imaji, 2017). Apabila mencermati temuan tersebut, perilaku bunuh diri di Gunung Kidul disebabkan oleh adanya tekanan beban hidup yang berdampak pada keadaan psikologis individu dan bukan merupakan takdir yang tidak dapat dihindari.

Oleh karena itu, pendekatan psikologis penting dilakukan untuk membongkar mitos Pulung Gantung ini, yaitu dengan mengkontekstualisasikan fenomena Pulung Gantung sebagai pokok masalah pada ranah psikologi. Penelitian ini akan berfokus pada latar belakang psikologis seseorang yang melakukan perilaku bunuh diri di Gunung Kidul. 


\section{Motif Psikologis Individu untuk Bunuh Diri}

Shneidman (1993) mendefinisikan perilaku bunuh diri sebagai sebuah perilaku pemusnahan secara sadar yang ditujukan pada diri sendiri oleh pelaku yang memandang perilaku bunuh diri sebagai solusi terbaik dari sebuah masalah. Sementara itu, O'Connor dan Nock (2014) mendefinisikan perilaku bunuh diri sebagai pikiran dan perilaku yang terkait dengan intensi individu untuk mengakhiri hidup mereka sendiri.

Bunuh diri merujuk pada semua kasus kematian yang dilakukan secara langsung maupun tidak langsung oleh korbannya sendiri, di mana korban menyadari akibat dari tindakannya tersebut (Durkheim, 2005). Lebih lanjut, Durkheim (2005) juga menyatakan bahwa bunuh diri juga dapat mencerminkan hubungan individu dengan masyarakatnya yang menekankan apakah individu terintegrasi dan teratur atau tidak dengan masyarakatnya. Kerentanan untuk melakukan perilaku bunuh diri pada individu akan meningkat apabila individu tersebut berada dalam situasi di mana harapannya pada masyarakat menurun dan rendahnya penerimaan atas kondisi kehidupan (Durkheim, 2005).

Shneidman (1993) menitikberatkan perilaku bunuh diri disebabkan oleh adanya psychache sebagai rasa sakit psikologis yang tak tertahankan berupa kesedihan, sakit hati maupun luka yang dapat dijadikan penyebab bunuh diri. Upaya perilaku bunuh diri merupakan sebuah tindakan refleksi dari tidak terpenuhinya kebutuhan psikologis yang spesifik. Rasa sakit yang tak tertahankan tersebut kemudian mendorong individu pada keputusan bahwa perilaku bunuh diri merupakan satu-satunya jalan keluar.

Beck dkk. (1975) menyebutkan bahwa perilaku bunuh diri disebabkan karena adanya keputusasaan dan pesimisme akan masa depan. Model ini terdiri dari tiga pandangan negatif mengenai diri, dunia, dan masa depan yang dapat diartikan dengan menganggap dirinya tidak berharga dan tidak berguna, menilai bahwa dunia terlalu menuntut, serta khawatir karena memiliki masa depan suram. Ketika skema kognitif ini aktif karena adanya kejadian hidup yang menekan, maka individu berisiko melakukan perilaku bunuh diri.

Joiner (2005) mengajukan tiga faktor penting yang dapat menyebabkan bunuh diri: 1). perasaan kesepian karena seseorang tidak termasuk bagian orang lain (thwarted belongingness); 2). perasaan tidak berguna karena seseorang merasa menjadi beban orang lain atau masyarakat (perceived burdensomeness); dan 3). kemampuan yang diperoleh untuk mengatasi rasa takut dan rasa sakit yang terkait dengan perilaku bunuh diri (acquired capability to self-injury). Dua konstruksi interpersonal pertama diasumsikan untuk mempromosikan keinginan untuk mati, sementara 
kemampuan untuk perilaku bunuh diri adalah fungsi dari pengalaman stres dan menyakitkan yang berulang, seperti trauma, luka sendiri, usaha sebelumnya, atau terpapar rasa sakit. Pengembangan kemampuan untuk melukai diri sendiri dapat juga disempurnakan oleh pikiran perilaku bunuh diri yang gigih.

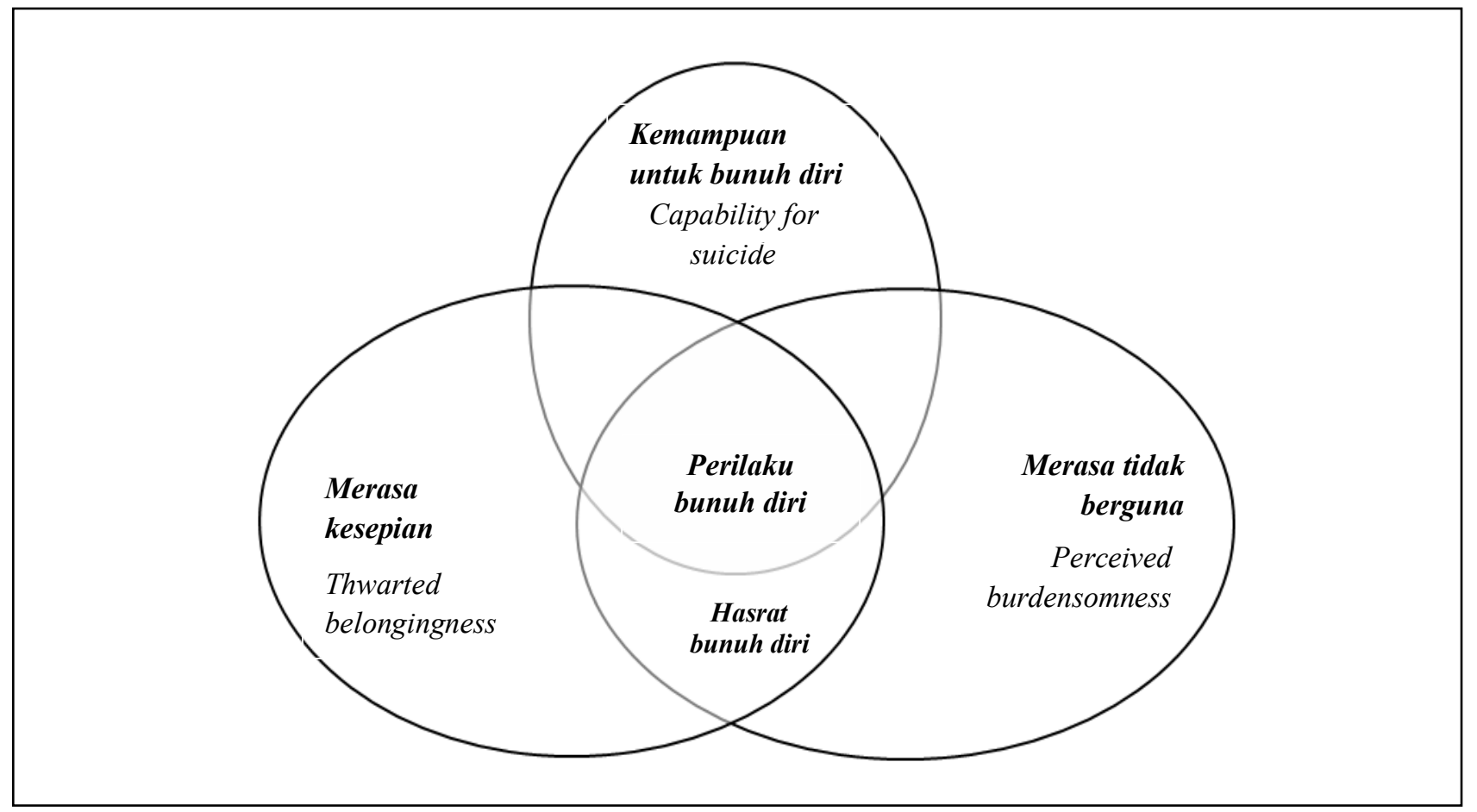

Figur 1. Model Interpersonal-Psychological of Suicidal Theory (Joiner, 2005)

Mengacu pada pendapat para ahli di atas, definisi perilaku bunuh diri dalam penelitian ini adalah pikiran-pikiran dan perilaku yang terkait dengan intensi individual untuk mengakhiri hidup mereka sendiri. Munculnya gagasan dan perilaku bunuh diri disebabkan oleh rasa sakit psikologis yang tak tertahankan dan merupakan akumulasi dari problematika psikososial yang dialami individu, yaitu perasaan kesepian karena seseorang tidak termasuk bagian orang lain (thwarted belongingness) dan perasaan tidak berguna karena seseorang merasa menjadi beban orang lain atau masyarakat (perceived burdensomeness). Faktor selanjutnya adalah kemampuan untuk melakukan perilaku bunuh diri (capability for suicide). Kemampuan ini didapatkan dari pengalaman hidup yang provokatif karena seringkali berhadapan pada keberanian dan ketidaksensitifan rasa sakit. 


\section{Tujuan Studi}

Penelitian ini bertujuan untuk mengidentifikasi faktor-faktor psikologis yang memengaruhi perilaku bunuh diri di Gunung Kidul. Lebih lanjut, penelitian ini akan menggambarkan bagaimana keterkaitan faktor psikologis tersebut dalam memicu munculnya ide perilaku bunuh diri. Hasil penelitian ini selanjutnya diharapkan dapat menjadi referensi bagi pihak-pihak yang terkait untuk menyusun langkah-langkah pencegahan perilaku bunuh diri.

\section{METODE}

\section{Partisipan}

Partisipan ialah seorang pemuda berusia 45 tahun yang berdomisili di wilayah Wonosari. Selain itu, juga terdapat informan penelitian yang merupakan pihak-pihak lain yang memiliki hubungan dengan partisipan penelitian, seperti saudara dekat keluarga, teman pelaku, atau tetangga.

Tabel 1. Partisipan Penelitian

\begin{tabular}{ccccc}
\hline No & Inisial & Usia & Status & Status Dalam Keluarga \\
\hline 1 & $\mathrm{P}$ & 45 & Partisipan & Suami/penyintas bunuh diri \\
2 & $\mathrm{I} 1$ & 44 & Informan & Istri \\
3 & $\mathrm{I} 2$ & 30 & Informan & Adik \\
4 & $\mathrm{I} 3$ & 40 & Informan & Tetangga dan perangkat desa \\
\hline
\end{tabular}

\section{Desain}

Penelitian ini bertujuan untuk mengungkap bagaimana dinamika psikologi yang melatarbelakangi perilaku bunuh diri di Gunung Kidul. Penelitian ini dilakukan di Kecamatan Wonosari. Kecamatan Wonosari merupakan wilayah dengan angka kejadian perilaku bunuh diri paling tinggi kurun waktu 2015-2017. Penelitian ini menggunakan pendekatan kualitatif fenomenologi, yang menekankan pada proses yang dialami oleh partisipan. Dalam pendekatan fenomenologi peneliti menggali peristiwa dan pengalaman yang dialami, dirasakan dan dimaknai dari sudut pandang partisipan (epoche) secara mendalam (Creswell, 2014). Pengambilan data dilakukan dengan melakukan wawancara mendalam dan observasi.

\section{Prosedur}

Identifikasi dan pendekatan dengan partisipan penelitian dilakukan bersama dengan Yayasan Inti Mata Jiwa (Imaji). Partisipan adalah salah satu dari penyintas yang didampingi oleh Imaji. Proses 
wawancara mendalam dilakukan di rumah partisipan. Teknik wawancara yang digunakan adalah wawancara semi terstruktur, yaitu wawancara yang berisi pertanyaan sebagai panduan. Selanjutnya, probing dilakukan untuk memperoleh kedalaman data. Panduan wawancara disusun mengacu pada faktor-faktor yang memengaruhi perilaku bunuh diri yang dikemukakan Joiner (2005). Selain itu, metode observasi juga dilakukan terhadap partisipan pada saat wawancara berlangsung.

\section{Teknik Analisis}

Penelitian ini menggunakan teknik analisis fenomenologi. Analisis dan interpretasi data penelitian ini dilakukan dalam beberapa tahap. Pertama, hasil wawancara dan observasi ditranskrip dan dipaparkan apa adanya. Observasi dilakukan pada saat wawancara dengan menggunakan teknik pencatatan secara bebas dan kualitatif dengan model diary description, di mana catatan observasi berisi tentang deskripsi partisipan dan perilaku partisipan. Kedua, dilakukan koding untuk mengkategorikan data wawancara dan observasi sesuai dengan fokus penelitian. Terakhir, peneliti melakukan analisis data dan penarikan kesimpulan penelitian.

\section{ANALISIS DAN HASIL}

Partisipan dalam penelitian adalah penyintas bunuh diri dan keluarganya. P adalah suami, seorang laki-laki paruh baya berusia 45 tahun. P memiliki istri bernama I1 dan dua orang anak yang telah dewasa. Anak perempuan P berusia 20 tahun dan saat ini bekerja di Jakarta, sementara anak laki-lakinya adalah siswa Sekolah Menengah Atas. Paska diamputasi kakinya, P tidak bekerja dan kebutuhan keluarga hanya ditopang oleh istri yang bekerja sebagai buruh cuci di sebuah penginapan kelas melati, tak jauh dari rumahnya. 


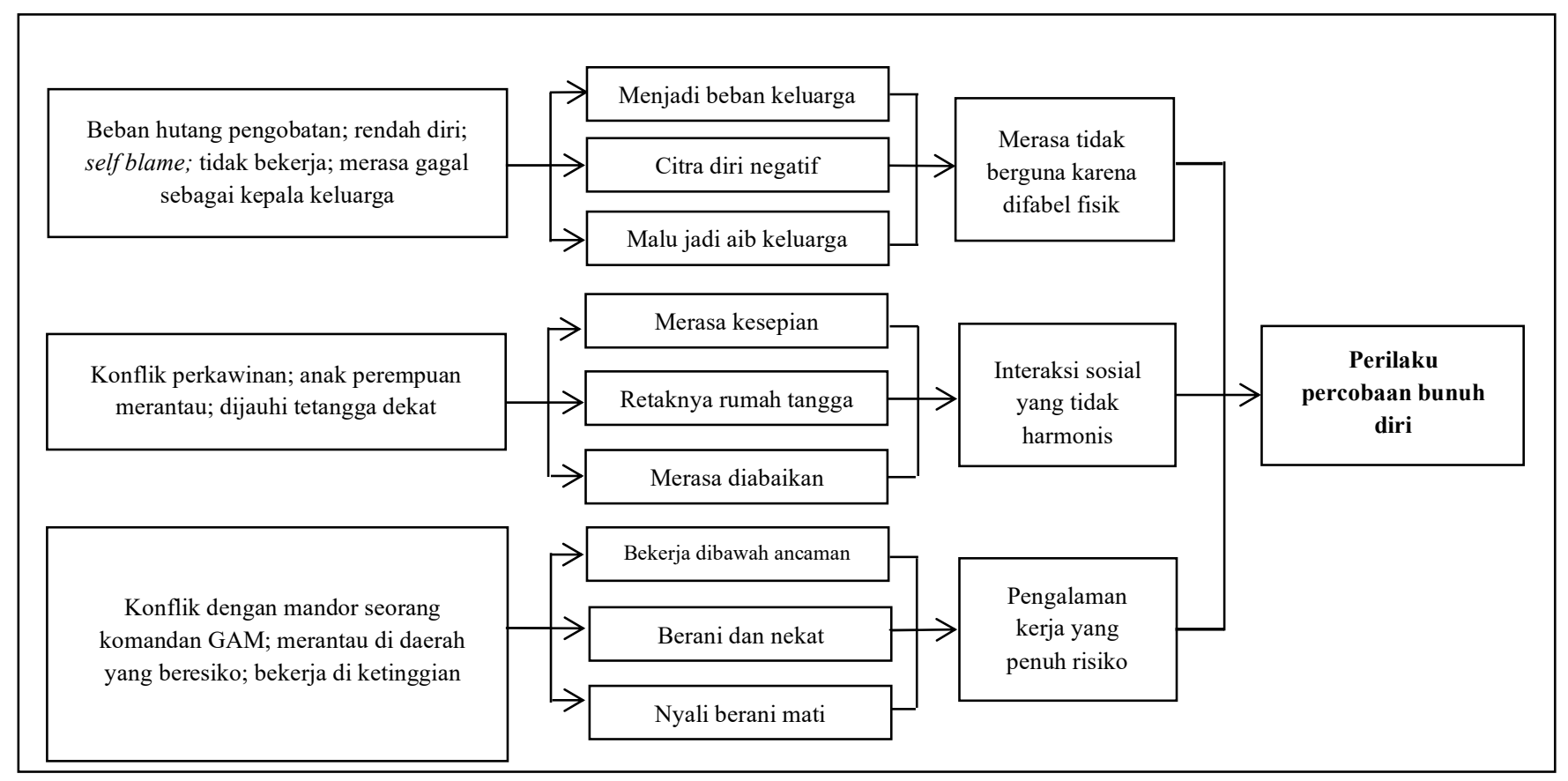

Figur 2. Tema-Tema Hasil Penelitian

Figur 2 menunjukkan hasil penelitian yang menggambarkan latar belakang psikologis yang memotivasi P melakukan perilaku bunuh diri. Terdapat beberapa rangkaian peristiwa yang dialami $\mathrm{P}$ yang memiliki dampak pada kondisi psikologisnya sebelum melakukan perilaku percobaan bunuh diri.

\section{Pekerjaan Penuh Risiko Partisipan}

Pengalaman paling menegangkan yang membuat $\mathrm{P}$ merasa berada antara hidup dan mati adalah ketika $\mathrm{P}$ menagih uang hasil kerjanya pada sang mandor. Pernah suatu ketika $\mathrm{P}$ menagih uang hasil kerjanya, tetapi $\mathrm{P}$ justru mendapatkan ancaman kekerasan secara fisik, yaitu dipukuli dan diintimidasi menggunakan senjata api oleh mandornya yang merupakan seorang kombatan GAM (Gerakan Aceh Merdeka).

Jadi saya diperingati ga bisa, mandornya diperingati juga ga bisa, saya dipukul mandornya dipukul.. pestol memang pestol. (P)

Pekerjaan yang dilakukan P untuk kehidupannya selalu memiliki risiko tinggi. Namun, P tidak mempedulikannya karena itu semua dilakukan demi mendapatkan penghasilan untuk menghidupi keluarganya. P juga pernah bekerja sebagai buruh bangunan menara pemancar sinyal telekomunikasi 
dengan tugas menyambung panel-panel besi dengan ketinggian minimal 25 meter. Tentu saja pekerjaan tersebut memiliki standar keamanan tinggi bagi pekerjanya. Namun, peneliti menilai bahwa hanya orang yang bernyali tinggi saja seperti P yang berani memanjat menara setinggi 25-75 meter. Meskipun pekerjaannya memiliki risiko yang tinggi, tetapi $\mathrm{P}$ tetap menjalaninya karena sepadan dengan upah yang didapatkan.

\section{Konflik Rumah Tangga}

Konflik rumah tangga yang terjadi pada P dan I1 menunjukkan kehidupan rumah tangga yang sebenarnya sudah tidak harmonis. Persoalan ekonomi, perilaku mabuk, dan kecemburuan menjadi pemicu keretakan rumah tangga mereka. Meskipun demikian, pernikahan P dan I1 masih dapat dipertahankan. Rasa kasih sayang dan hubungan hangat antara suami dan istri juga tidak tampak dalam kehidupan rumah tangga $\mathrm{P}$ dan I1. Ketiadaan hubungan hangat keduanya ditandai dengan kepergian I1 pulang ke rumah orangtuanya tanpa pamit kepada $\mathrm{P}$.

Itu pernah dua kali saya pergi dari rumah karena dia minum. Saya ga dikasih nafkah sama sekali. (I1)

Permasalahan ekonomi sering menjadi topik dalam pertengkaran P dan I1. Sebagai istri, I1 merasa memiliki hak untuk mempertanyakan penghasilan suaminya karena $\mathrm{P}$ dirasa tidak cukup menafkahi keluarga selama merantau. Menurut I1, sebagai pekerja P dianggap cukup sukses ketika merantau di Kalimantan, terbukti ketika P mampu mengajak tetangganya untuk ikut bekerja bersama. Hal ini memunculkan kecurigaan bahwa uang yang selama ini dihasilkan tidak diberikan kepada keluarga, sementara keluarga di Jawa secara ekonomi cukup kekurangan.

Masa kerja sampai Kalimantan sampai Aceh kok ga bawa uang. Itu mau gimanapun pasti timbul pertanyaan, ini bener-bener ga bawa uang ini dibuat seneng-seneng sendiri apa bener kerja, ya seperti itu. Jadinya kan otomatis tidak semua orang itu kalau dikasih tau bisa menerima, pasti ada rasa curiga, ngga percaya 'masa iya, apa iya'. (P)

Oleh karena emosi, I1 menampar P sebanyak dua kali dan ini merupakan hal yang tidak pernah terjadi sebelumnya selama mereka berdua bertengkar. Selanjutnya, I1 pergi meninggalkan rumah menuju ke rumah mertuanya. Di sana, I1 ditenangkan oleh mertuanya sekaligus mendapatkan empati dari sang mertua karena mertua I1 telah paham betul sifat dan perilaku P. Seperti biasa, P 
kemudian mencari-cari istrinya. Oleh mertuanya, I1 sengaja disembunyikan agar P kebingungan dan menjadi jera.

\section{Kaki Diamputasi karena Sakit}

Pasca satu kakinya diamputasi, P mengalami perubahan hidup yang drastis. P tidak mampu lagi diandalkan sebagai tumpuan ekonomi keluarga. $\mathrm{P}$ juga kehilangan pekerjaan yang selama ini yang menjadi pokok penghasilan keluarga.

Beban hutang yang menumpuk tidak lagi sanggup untuk dilunasi. Belum lagi hutang baru yang digunakan untuk membayar biaya rawat jalan pasca amputasi. P semakin merasa malu, apalagi ketika melihat istrinya yang saat ini bekerja keras sebagai buruh cuci. Naluri sebagai kepala rumah tangga pada diri P tidak dapat menerima keadaan seperti saat ini. P merasa bukan lagi tumpuan keluarga, tetapi justru menjadi beban dan aib bagi keluarganya.

P merasa menjadi sosok yang tidak berguna lagi, baik sebagai laki-laki maupun sebagai kepala rumah tangga. Sebagai kepala rumah tangga, P tidak mampu memberikan nafkah lagi kepada keluarganya. Oleh karena sudah tidak dapat bekerja seperti dulu, P hanya menggantungkan nasibnya pada I1. I1 bekerja sebagi tukang cuci di sebuah penginapan wisata yang tak jauh dari rumahnya. Penghasilan yang didapatkan tidak sebanding dengan pengeluaran yang harus dikeluarkan. Hal tersebut semakin menambah beban hati P yang saat ini tidak mampu bekerja lagi.

\section{Interaksi Sosial yang Tidak Hangat}

Setelah kehilangan satu kaki, P merasa mulai dijauhi oleh tetangganya. Hal ini P rasakan ketika ia sedang beraktivitas di luar dan berpapasan dengan para tetangga, tetapi jarang ada tetangganya yang menyapa. Bahkan, tetangga $\mathrm{P}$ seolah-olah tidak melihat dirinya, padahal dulu mereka sering beraktivitas bersama. Hal ini membuat $\mathrm{P}$ merasa tidak memiliki teman seperti dahulu dan membuat $\mathrm{P}$ berpikir bahwa teman-temannya malu berteman dengan dirinya yang cacat.

Ya kados kulo sanjangke riyen. Ibaratnya dulu itu makan nasi sepiring berdua katakanlah, saat ini masalah seakan-akan ketemu di jalan ngerti tapi pura-pura ga tau. Kulo nggeh dalam hati mikir, apa dia itu malu saya seperti ini atau dia itu perkewuh. Tapi ya saya kembali lagi, wajar kalau dia sudah tidak mau berteman dengan saya, paling dia ini malu. (P)

Memiliki cacat membuat $\mathrm{P}$ merasa rendah diri dan tidak lagi beraktivitas di luar seperti dahulu. $\mathrm{P}$ hanya berada di rumah saja, duduk, tidur, makan, dan aktivitas di dalam rumah. Ditambah 
lagi, adanya respons negatif dari tetangga yang membuat $\mathrm{P}$ lebih banyak mengurung diri di rumah. Meskipun sesekali P keluar untuk bertemu dengan tetangganya, terkadang respons tetangga yang negatif membuatnya menjadi tidak nyaman. Misalnya, ketika bercanda sering menyinggung ke arah fisik P.

Iya.. katakanlah hujan, pada pulang 'ayo lari-lari-lari' kan saya sendiri sudah kesinggung. 'Ya sana yang ih komplit, saya sudah tidak komplit', saya hanya menjawab seperti itu. Karena sekecil itu, memang mungkin tujuannya bukan saya, tapi kan saya kerasa. (P)

Lambat laun keadaan interaksi dengan lingkungan sosial mulai memengaruhi P, apalagi dengan kondisinya yang kini hanya memiliki satu kaki. P juga cenderung menarik diri dari aktivitas sosial di kampungnya. P menyendiri di rumah, menonton TV, mendengarkan radio, serta berkunjung ke rumah adiknya ketika sedang bosan.

Gimana ya, jadi dalam arti sepinya saya itu memang orang tua masih komplit, saudara ada. Tetangga juga ada. Tapi kalau siang hari kan otomatis yang di rumah itu kebanyakan perempuan, masa setiap hari main dengan perempuan kan ga baik. Memang katakanlah hanya ngobrol, tapi kan di mata orang jahat kan ya macemmacem. Katakanlah misal saya mau ke rumah ibu saya, dan jarak dari rumah ke sini kalau jalan kan lumayan jauh jadi otomatis ya saya bilang tadi yang jadi merepotkan kalau ke kamar mandi itu. Memang misal ke kamar mandi diantar katakanlah, tapi masa setiap itu ya diantar pulang. Mungkin satu kali dua kali ga papa, tapi kalau berlanjutan masa iya saya seperti ga punya perasaan. Ngerasa sepi itu kalau lagi stress-stresnya nyetel lagu yang kencang. (P)

\section{DISKUSI}

Perilaku bunuh diri sesungguhnya bukanlah perilaku yang spontan atau tiba-tiba saja muncul. Perilaku bunuh diri didahului oleh predisposisi psikologis berupa ketidakberdayaan (Valentina \& Helmi, 2016), frustasi (Mukarromah \& Nuqul, 2014), dan kesepian (Dewi \& Hamidah, 2013). Mengacu pada hasil penelitian, munculnya perilaku bunuh diri pada partisipan merupakan akumulasi dari persoalan psikologis yang bertumpuk. Hubungan rumah tangga yang penuh konflik dan hubungan sosial yang tidak hangat menyebabkan partisipan merasa tidak lagi memiliki makna dalam berhubungan dangan orang lain. Berdasarkan hasil yang telah diuraikan sebelumnya, Figur 3 merangkum dinamika antar aspek psikologis yang muncul pada diri partisipan yang menjelaskan tentang perilaku bunuh diri yang dilakukan. 


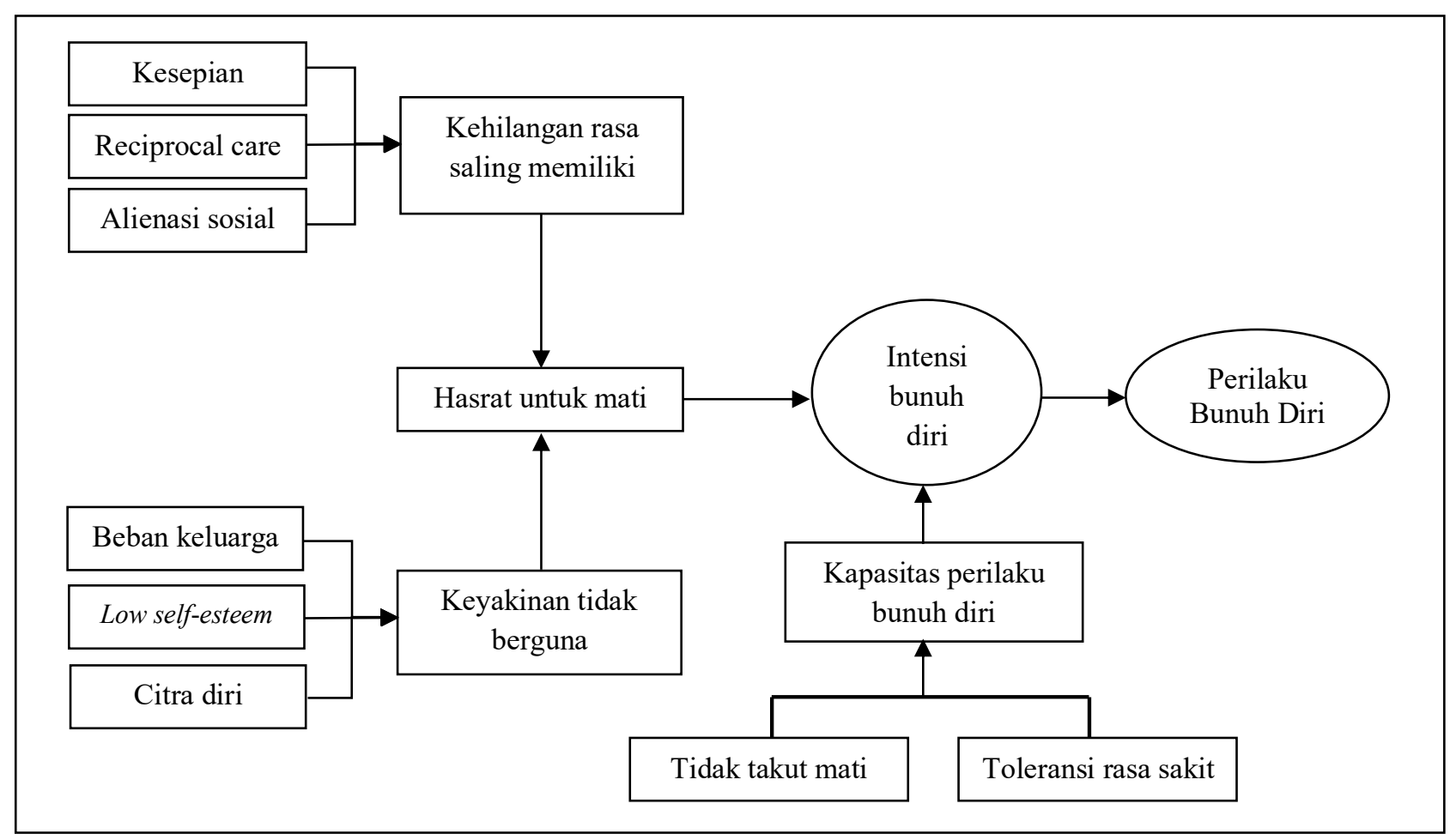

Figur 3. Dinamika Psikologis Partisipan Penyintas Perilaku Bunuh Diri

Hasil studi akan didiskusikan menurut tiga aspek psikologis yang melatarbelakangi kemunculan gagasan perilaku bunh diri. Tiga aspek tersebut adalah kehilangan rasa saling memiliki, keyakinan tidak berguna, dan aspek kapasitas atau kemampuan perilaku bunuh diri. Pembahasan diakhiri dengan mempertanyakan Pulung Gantung sebagai penyebab perilaku bunuh diri.

\section{Kehilangan Rasa Saling Memiliki (Thwarted Belonginess)}

Hasil penelitian ini menunjukkan adanya konflik di dalam rumah tangga partisipan. Konflik ini membuat hubungan suami-istri partisipan menjadi tidak harmonis dan menjadikan partisipan merasa tidak lagi dipedulikan oleh istriya. Dalam kehidupan sosial di luar rumah, perilaku partisipan yang dianggap tidak sesuai dengan kebiasaan masyarakat sekitar, seperti minuman keras, pamer, dan bermain perempuan menyebabkan partisipan dijauhi oleh warga. Banyak warga yang berpendapat bahwa kehilangan kaki pada partisipan merupakan hukuman atas perilakunya selama ini. Kondisi yang seperti ini, terutama setelah kehilangan kaki, menyebabkan partisipan merasa tidak ada lagi orang yang mempedulikan dirinya. Hal ini menyebabkan partisipan merasa kehilangan rasa memiliki dengan orang-orang terdekatnya. 
Partisipan merasa tidak lagi memiliki hubungan sosial yang bermakna baginya, padahal relasi sosial yang menyenangkan merupakan kebutuhan mendasar individu. Dengan demikian, yang terjadi ialah partisipan merasa kesepian dan tertekan (Baumeister \& Leary, 1995). Penyebabnya adalah mulai berkurangnya keharmonisan dalam rumah tangga bersama istrinya. Konflik dalam keluarga dapat menyebabkan seseorang kehilangan hubungan timbal balik kasih sayang (reciprocal care) (Joiner, 2005; Van Orden, Witte, Cukrowicz, dkk., 2010). Kehilangan hubungan timbal balik kasih sayang dapat membuat individu merasa tidak memiliki dukungan sosial dari orang-orang terdekatnya. Akibatnya terjadi ketegangan psikis, munculnya psikopatologi dan muncul ide bunuh diri (Choi \& Marks, 2008).

Keretakan hubungan sosial dengan lingkungan juga merupakan faktor yang berpengaruh pada keputusan perilaku bunuh diri partisipan. Penyebabnya adalah partisipan merasa malu dengan kondisi rumah tangga yang tidak harmonis serta kondisi kecacatan fisiknya, sehingga partisipan menarik diri dari pergaulan sosial. Munculnya perasaan rendah diri merupakan indikator kuat konsep diri yang negatif (Ratih \& Tobing, 2016). Lebih lanjut, di banyak kasus percobaan bunuh diri, pelaku memiliki profil konsep diri negatif. Biroli (2018) menjelaskan bahwa ketiadaan integrasi sosial menyebabkan individu melakukan tindakan bunuh diri (egoistic suicide). Dalam perspektif sosiologi, egoistic suicide muncul karena individu merasa sendirian akibat lingkungan kurang dapat menerimanya dengan baik.

Memiliki hubungan sosial (sense of belonginess) yang bermakna merupakan kebutuhan dasar psikologis yang penting, terutama ketika individu menghadapi masalah. Studi menunjukan faktor protektif perilaku bunuh diri muncul dari dukungan sosial (Kleiman \& Liu, 2013) dan rasa saling memiliki (Hagerty \& Williams, 1999). Sebaliknya kehilangan dukungan sosial dan rasa saing memiliki lain merupakan persoalan psikologis serius yang berujung pada keinginan melakukan bunuh diri (Chu dkk., 2018; You dkk., 2011).

\section{Persepsi Tidak Berguna (Perceived Burdensomness)}

Kehilangan kaki karena amputasi menyebabkan partisipan menjadi individu yang cacat fisik. Kondisi fisik yang dimiliki partisipan membatasi ruang gerak dan aktivitas kerjanya. Hal ini menyebabkan partisipan tidak lagi mampu diandalkan sebagai tulang punggung keluarga. Di sisi yang lain, beban ekonomi keluarga partisipan semakin berat. Namun, partisipan tidak lagi dapat memenuhi tanggung jawab dan kewajibannya sebagai kepala rumah tangga untuk menafkahi keluarganya. Hal 
ini menimbulkan beban psikologis bagi partisipan terkait dengan ketidakmampuannya memenuhi tanggung jawab sebagai kepala rumah tangga.

Kondisi psikologis yang dialami pada partisipan dapat dipahami karena perubahan kondisi fisik pada karakteristik usia partisipan dapat menyebabkan stres (Hurlock, 1998). Temuan ini mengkonfirmasi hasil studi yang dilakukan oleh Puspasari dan Alfian (2012), Jones dkk. (2014), dan Senra dkk. (2012) bahwa kecacatan fisik yang didapatkan pada usia dewasa madya akan mengakibatkan depresi. Kondisi paling ekstrim dari kecacatan fisik yang diperoleh dapat menyebabkan keinginan untuk bunuh diri. Penyandang disabilitas fisik memiliki risiko tinggi terhadap perilaku bunuh diri dibandingkan orang-orang yang tidak memiliki disabilitas (Khazem, 2018; Van Orden, Witte, Cukrowicz, dkk., 2010).

Penyebabnya individu yang memiliki kondisi kecacatan yang didapat setelah lahir cenderung memiliki konsep diri yang negatif(Bogart, 2014). Seperti halnya pada partisipan, kecacatannya sering menjadi bahan candaan dan hal ini membuat partisipan merasa tidak nyaman dan rendah diri. Senada dengan hal ini, Sulaeman (1995) mengungkapkan bahwa profil psikologis individu dengan kecacatan bukan faktor bawaan cenderung mencerca diri sendiri, memandang orang lain secara tidak adil, menolak dirinya, suka menyakiti diri sendiri, dan sering berbuat sesuatu yang menyebabkan orang lain memandang rendah kepada dirinya. Hal ini menunjukkan bahwa individu sulit menerima kondisi dirinya sendiri saat ini. Sari (2012) menemukan hubungan yang positif antara citra diri dengan konsep diri pada tuna daksa dewasa. Rendahnya citra diri individu akibat kecacatan yang dimiliki membuat konsep diri individu tersebut semakin rendah juga.

Kondisi sebaliknya terjadi apabila partisipan mendapatkan dukungan sosial yang positif dari lingkungan terdekatnya. Dukungan sosial yang didapatkan dari keluarga dan lingkungan merupakan kunci agar individu dengan disabilitas fisik mampu mengatasi persoalan psikologis yang dihadapi. Adelina dkk. (2018) menyebutkan bahwa individu yang mendapatkan dukungan sosial tinggi mengalami hal-hal positif dalam hidupnya, mempunyai harga diri yang lebih tinggi, konsep diri yang lebih baik, dan kecemasan yang lebih rendah.

Penyandang difabel sering dianggap tidak berguna di masyarakat, bahkan penyandang difabel beranggapan bahwa dirinya hanya merepotkan orang-orang di sekitarnya. Individu yang mengalami keterbatasan, baik dari faktor bawaan maupun faktor kecelakaan, mempunyai pandangan negatif terhadap kondisinya. Pandangan negatif tersebut menjadi stereotip, prasangka, dan batasan (limitation) dari masyarakat yang memandangnya maupun dirinya sendiri karena merasa tidak mampu (Lahey, 2012). 
Kondisi psikologis tersebut menimbulkan keyakinan pada diri partisipan bahwa dirinya sudah tidak berguna lagi bagi orang. Lebih lanjut, dua komponen pembentuk keyakinan ini adalah merasa menjadi beban bagi orang lain dan benci terhadap dirinya sendiri. Keyakinan menjadi individu yang tidak berguna merupakan prediktor yang kuat pada keinginan untuk melakukan tindakan bunuh diri (Chu dkk., 2018; De Beurs dkk., 2019; Van Orden, Witte, Cukrowicz, dkk., 2010).

\section{Kapasitas atau Kemampuan untuk Perilaku Bunuh Diri (Capability to Enact Suicide)}

Latar belakang pekerjaan yang dilakukan partisipan selama ini penuh risiko. Meskipun demikian, partisipan tetap menjalaninya dengan motivasi untuk mencukupi kebutuhan keluarganya. Hal ini juga menunjukan karakter yang dimiliki oleh partisipan sebagai sosok yang nekat, keras kepala, berani, dan tidak mengenal rasa takut. Ditambah lagi partisipan juga melewati pengalaman menyakitkan, yaitu kehilangan anggota tubuh akibat sakit yang serius pada kaki. Tidak dapat dipungkiri bahwa dalam kehidupan partisipan seringkali terjadi situasi risiko bertaruh nyawa.

Meyer dkk. (2017) menyebutkan bahwa kemampuan atau kapasitas perilaku bunuh diri mengacu pada kemampuan individu untuk mengatasi ketakutan kematian, keinginan untuk bertahan hidup, dan ketahanan menghadapi rasa sakit. Akumulasi dari pengalaman hidup yang penuh tekanan, serta bertahan dari terpaparnya penyakit dan trauma meningkatkan kemampuan untuk bunuh diri (Van Orden, Witte, Cukrowicz, dkk., 2010). Individu yang memiliki kemampuan perilaku bunuh diri telah memiliki toleransi yang tinggi terhadap rasa sakit berulang dan tidak takut menghadapi kematian.

Pengalaman partisipan melewati masa menyakitkan ketika mengalami rasa sakit pada kaki hingga membuat keputusan melakukan amputasi kaki menjadikan partisipan memiliki toleransi yang tinggi terhadap rasa sakit fisik. Meskipun secara tidak langsung berpengaruh, perilaku yang memicu adrenalin (provocative event), seperti tindakan kriminal, seks bebas, perkelahian fisik, dan melakukan pekerjaan di ketinggian dilaporkan memiliki skor kapasitas perilaku bunuh diri yang relatif tinggi (Van Orden, Witte, Gordon, dkk., 2008). Memiliki kapasitas atau kemampuan perilaku bunuh diri berperan meningkatkan intensi atau niat untuk melakukan bunuh diri.

\section{Mitos Pulung Gantung dan Upaya Pencegahan Perilaku Bunuh Diri?}

Hasil penelitian ini menunjukkan bahwa penyintas bunuh diri mengalami tekanan psikologis sebelum akhirnya melakukan perilaku bunuh diri. Apabila isu psikologis ini dapat dikelola dan dikurangi, maka perilaku bunuh diri dapat dihindari. Namun, masyarakat seringkali mengkaitkannya 
dengan Pulung Gantung yang merupakan sebuah takdir yang tidak dapat dihindari. Hal ini dapat terjadi karena adanya post factum explanation, di mana biasanya setelah kejadian masyarakat baru dapat menyimpulkan peristiwa sebagai Pulung Gantung (Darmaningtyas, 2002). Kejadian ini terus berulang disertai interpretasi yang sama, sehingga membentuk persepsi perilaku bunuh diri yang terjadi akibat adanya pulung.

Masih diyakininya mitos Pulung Gantung menunjukkan bahwa tingkat pengetahuan masyarakat Gunung Kidul masih rendah tentang perilaku bunuh diri. Hal ini disebabkan karena kehadiran mitos sebagai cerminan kebudayaan suatu masyarakat dalam menghadapi sebuah fenomena. Essebo (2018) mengartikan mitos sebagai cara pandang primitif untuk menjelaskan dunia yang belum mampu dipahami dan dikendalikan.

Mitos Pulung Gantung digunakan untuk menyamarkan fakta problematika psikososial yang melarbelakangi perilaku bunuh diri. Mulyani dan Eridiana (2018) menyebutkan bahwa persepsi mengenai Pulung Gantung mendorong anggota masyarakat lainnya untuk menyesuaikan pada klaim atau persepsi yang telah dibangun secara kolektif dalam masyarakat. Persoalan selesai apabila diyakini penyebabnya adalah Pulung Gantung, yaitu takdir yang tidak dapat dihindari.

Dampak yang timbul adalah masyarakat kehilangan daya berpikir kritis untuk mengatasi permasalahan yang ada. Masyarakat juga menjadi tidak peka kepada penyintas dan keluarga tentang problematika psikososial yang melatarbelakangi perilaku bunuh diri. Kemudian, upaya penyelesaian secara psikologis menjadi terabaikan karena bunuh diri diyakini sebagai takdir Tuhan yang berada di luar kuasa manusia untuk menghindarinya.

\section{SIMPULAN DAN SARAN}

\section{Simpulan}

Penelitian ini telah menggambarkan dinamika faktor-faktor psikologis yang melatarbelakangi seorang individu untuk melakukan percobaan bunuh diri di Gunung Kidul. Hasil penelitian menunjukkan bahwa perilaku bunuh diri disebabkan oleh faktor-faktor psikologis yang saling berkaitan dalam diri individu, yaitu kehilangan rasa saling memiliki (thwarted belonginess) dan persepsi tidak lagi berguna (burdensomness), yang menjadi faktor pendorong munculnya keinginan untuk mengakhiri hidup (desire of death). Kurangnya informasi kesehatan mental, khususnya tentang perilaku bunuh diri, menyebabkan masyarakat cenderung mempercayai mitos Pulung Gantung. 
Selain itu, mitos Pulung Gantung cenderung dipakai untuk menyamarkan fakta problematika psikososial yang melatarbelakangi perilaku bunuh diri.

\section{Saran Teoretis}

Penelitian ini mengindikasikan bahwa adanya mitos yang dipercaya oleh masyarakat setempat (Pulung Gantung) menyamarkan permasalahan psikologis pemicu perilaku bunuh diri. Oleh karena itu, peneliti selanjutnya disarankan untuk mengkaji lebih lanjut tentang faktor-faktor protekif yang sensitif terhadap budaya dan kearifan lokal untuk memelihara kesehatan mental bagi masyarakat dan para penyintas perilaku bunuh diri.

\section{Saran Praktis}

Keluarga menjadi faktor pendukung pokok dalam upaya pencegahan bunuh diri (Faria dkk., 2020). Oleh karena itu, dukungan antar anggota keluarga perlu dipelihara sebagai faktor protektif terhadap perilaku bunuh diri, dengan membina hubungan interpersonal yang harmonis, mengurangi konflik dengan cara mengembangkan penyelesaian konflik bersama anggota keluarga lain. Kemudian, keluarga juga perlu menjadi sosok yang dapat diandalkan apabila individu sedang menghadapi permasalahan. Penting bagi keluarga untuk memiliki pengetahuan dan kepedulian untuk mengidentifikasi gejala psikopatologis dan kecenderungan perilaku bunuh diri di keluarganya, serta melakukan langkah mitigasi dengan berkoordinasi dengan petugas kesehatan setempat atau kader kesehatan untuk mendapat penanganan yang tepat.

Perlu adanya kesadaran masyarakat bahwa perilaku bunuh diri merupakan permasalahan bersama yang penting untuk diperhatikan. Untuk itu, masyarakat diharapkan dapat menumbuhkan sikap dan perilaku yang positif dalam interaksi sehari-hari, sehingga setiap individu merasa saling memiliki dan tidak merasa dikucilkan. Selain itu, masyarakat juga perlu meningkatkan keterlibatan dalam upaya-upaya konkret dalam pencegahan perilaku bunuh diri dan pendampingan terhadap penyintas bunuh diri. Pendampingan berbasis masyarakat bagi penyintas akan lebih efektif untuk mengurangi gejala-gejala psikologis penyebab kemunculan perilaku bunuh diri.

Terakhir, penelitian ini memberikan saran kepada pemerintah setempat untuk menempatkan sudut pandang psikologis dalam usaha-usaha pencegahan upaya perilaku bunuh diri, yaitu bersinergi dengan berbagai komponen masyarakat, seperti kader-kader desa, tokoh masyarakat, dan tokoh agama, dalam promosi kesehatan, deteksi dini, pendampingan masyarakat, dan peningkatan pelayanan kesehatan jiwa di puskesmas. Menjadi penting untuk pemerintah dalam memformulasikan 
langkah strategis untuk memelihara, bahkan memperkaya, kearifan lokal tetapi tetap menjaga kesehatan mental warganya.

\section{UCAPAN TERIMA KASIH}

Ucapan terima kasih ditujukan kepada LSM IMAJI yang telah memberikan bantuan teknis dan non-teknis dalam proses penelitian.

\section{REFERENSI}

Adelina, F., Akhmad, S. K., \& Hadi, C. (2018). Bagaimana agar penyandang tuna daksa mampu menjadi pribadi yang bahagia? Jurnal Sains Psikologi, 7(2), 119-125. https://doi.org/10.17977/um023v7i22018p119

Ahmed, H. U., Hossain, M. D., Aftab, A., Soron, T. R., Alam, M. T., Chowdhury, M. W. A., \& Uddin, A. (2017). Suicide and depression in the World Health Organization South-East Asia Region: A systematic review. WHO South-East Asia Journal of Public Health, 6(1), 60-66. https://doi.org/10.4103/2224-3151.206167

Ardanareswari, I. (2020). Sejarah sati: Tradisi bakar diri para janda yang bermula dari India. Tirto.Id. https://tirto.id/sejarah-sati-tradisi-bakar-diri-para-janda-yang-bermula-dari-india-evFi

Baumeister, R. F., \& Leary, M. R. (1995). The need to belong: Desire for interpersonal attachments as a fundamental human motivation. Psychological Bulletin, 117(3), 497-529. https://doi.org/10.1037/0033-2909.117.3.497

Beck, A. T., Kovacs, M., \& Weissman, A. (1975). Hopelessness and suicidal behavior: An overview. JAMA: The Journal of the American Medical Association, 234(11), 1146-1149. https://doi.org/10.1001/jama.1975.03260240050026

Biroli, A. (2018). Bunuh diri dalam perspektif sosiologi. Simulacra: Jurnal Sosiologi, 1(2), 213-223. https://doi.org/10.21107/sml.v1i2.4996

Bogart, K. R. (2014). The role of disability self-concept in adaptation to congenital or acquired disability. Rehabilitation Psychology, 59(1), 107-115. https://doi.org/10.1037/a0035800

Choi, H., \& Marks, N. F. (2008). Marital conflict, depressive symptoms, and functional impairment. Journal of Marriage and Family, 70(2), 377-390. https://doi.org/10.1111/j.17413737.2008.00488.x 
Chu, C., Rogers, M. L., Gai, A. R., \& Joiner, T. E. (2018). Role of thwarted belongingness and perceived burdensomeness in the relationship between violent daydreaming and suicidal ideation in two adult samples. Journal of Aggression, Conflict and Peace Research, 10(1), 1123. https://doi.org/10.1108/JACPR-10-2016-0255

Creswell, J. W. (2014). Research design: Qualitative, quantitative, and mixed methods approaches (4th ed.). SAGE.

Darmaningtyas. (2002). Pulung Gantung: Menyingkap tragedi bunuh diri di Gunung Kidul. Salwa Press.

De Beurs, D., Fried, E. I., Wetherall, K., Cleare, S., O’ Connor, D. B., Ferguson, E., O’Carroll, R. E., \& O’ Connor, R. C. (2019). Exploring the psychology of suicidal ideation: A theory driven network analysis. Behaviour Research and Therapy, 120(May), 103419. https://doi.org/10.1016/j.brat.2019.103419

Dewi, A. K. L., \& Hamidah. (2013). Hubungan antara kesepian dengan ide bunuh diri pada remaja dengan orangtua yang bercerai. Jurnal Psikologi Klinis Dan Kesehatan Mental, 2(03), 24-33.

Durkheim, E. (2005). Suicide: A study in sociology (2nd ed.). Routledge.

Essebo, M. (2018). A mythical place: A conversation on the earthly aspects of myth. Progress in Human Geography, 43(3), 515-530. https://doi.org/10.1177/0309132518768426

Fahrudin, A. (2012). Fenomena bunuh diri di Gunung Kidul : Catatan tersisa dari lapangan. Jurnal Informasi, 17(01), 13-19.

Faria, M., Santos, M. R., Sargento, P., \& Branco, M. (2020). The role of social support in suicidal ideation: A comparison of employed vs. unemployed people. Journal of Mental Health, 29(1), 52-59. https://doi.org/10.1080/09638237.2018.1487538

Felicitas, (2015, D. September 12). National Geographic. https://nationalgeographic.grid.id/read/13301467/bunuh-diri-di-usia-produktif

Hagerty, B. M., \& Williams, R. A. (1999). The effects of sense of belonging, social support, conflict, and loneliness on depression. Nursing Research, 48(4), 215-219. https://doi.org/10.1097/00006199-199907000-00004

Hurlock, E. B. (1998). Perkembangan anak (1st ed.). Erlangga.

Imaji. (2017). Mengapa seseorang melakukan bunuh diri? https://imaji.or.id/mengapa-seseorangmelakukan-bunuh-diri/

Joiner, T. (2005). Why people die by suicide. Harvard University Press.

Jones, K. H., Jones, P. A., Middleton, R. M., Ford, D. V., Tuite-Dalton, K., Lockhart-Jones, H., Peng, 
J., Lyons, R. A., John, A., \& Noble, J. G. (2014). Physical disability, anxiety and depression in people with MS: An internet-based survey via the UK MS register. PLoS ONE, 9(8), 1-9. https://doi.org/10.1371/journal.pone.0104604

Katadata (2016, Desember 22). Di provinsi mana banyak orang bunuh diri? https:/databoks.katadata.co.id/datapublish/2016/12/22/jawa-tengah-provinsi-dengan-kasusbunuh-diri-terbanyak-di-indonesia

Khazem, L. R. (2018). Physical disability and suicide: Recent advancements in understanding and future directions for consideration. Current Opinion in Psychology, 22, 18-22. https://doi.org/10.1016/j.copsyc.2017.07.018

Kleiman, E. M., \& Liu, R. T. (2013). Social support as a protective factor in suicide: Findings from two nationally representative samples. Journal of Affective Disorders, 150(2), 540-545. https://doi.org/10.1016/j.jad.2013.01.033

Lahey, B. B. (2012). Psychology: An introduction (11th ed.). McGraw-Hill.

Lestari, S., \& Budhi, O. (2017, September 10). Mitos pulung gantung dan upaya menangani kasus bunuh diri di Gunung Kidul. BBC. https://www.bbc.com/indonesia/indonesia-41194325

Meyer, C., Irani, T., Hermes, K., \& Yung, B. (2017). Explaining suicide: Patterns, motivations, and what notes reveal. Academic Press. https://corescholar.libraries.wright.edu/books/143

Mukarromah, L., \& Nuqul, F. L. (2014). Dinamika psikologis pada pelaku percobaan bunuh diri. Psikoislamika: Jurnal Psikologi Dan Psikologi Islam, 11(2). https://doi.org/10.18860/psi.v11i2.6387

Mulyani, A. A., \& Eridiana, W. (2018). Faktor-faktor yang melatarbelakangi fenomena bunuh diri di Gunung Kidul. Sosietas, 8(2), 510-516. https://doi.org/10.17509/sosietas.v8i2.14593

O’Connor, R. C., \& Nock, M. K. (2014). The psychology of suicidal behaviour. The Lancet Psychiatry, 1(1), 73-85. https://doi.org/10.1016/S2215-0366(14)70222-6

Puspasari, D., \& Alfian, I. N. (2012). Makna hidup penyandang cacat fisik postnatal karena kecelakaan. Jurnal Psikologi Klinis Dan Kesehatan Mental, 1(03), 133-139.

Rochmawati, I. (2009). Nglalu: Melihat fenomena bunuh diri dengan hati (Cet. 1.). Jejak Kata Kita. Santosa, B. I., \& Daksinarga, W. (2003). Tali pati : Kisah-kisah bunuh diri di Gunung Kidul (1st ed.). Jalasutra.

Sari, D. N. P. (2012). Hubungan antara body image dan self-esteem pada dewasa awal tuna daksa. Caliyptra: Jurnal Ilmiah Mahasiswa Universitas Surabaya, 1(1), 1-9. https://doi.org/10.1097/00001756-199606170-00005 
Senra, H., Oliveira, R. A., Leal, I., \& Vieira, C. (2012). Beyond the body image: A qualitative study on how adults experience lower limb amputation. Clinical Rehabilitation, 26(2), 180-191. https://doi.org/10.1177/0269215511410731

Shneidmann, E. (1993). Comentary suicide as psyache. The Journal of Nervous and Mental Disease, 181(3), 145-147. https://doi.org/https://doi.org/10.1097/00005053-199303000-00001

Sulaeman, D. (1995). Psikologi remaja: Dimensi-dimensi perkembangan. Mandar Maju.

Valentina, D. T., \& Helmi, F. A. (2016). Ketidakberdayaan dan perilaku bunuh diri: Meta-analisis. Buletin Psikologi, 24(2), 123-135. https://doi.org/10.22146/buletinpsikologi.18175

Van Orden, K. A., Witte, T. K., Cukrowicz, K. C., Braithwaite, S. R., Selby, E. A., \& Joiner, T. E. (2010). The interpersonal theory of suicide. Psychological Review, 117(2), 575-600. https://doi.org/10.1037/a0018697

Van Orden, K. A., Witte, T. K., Gordon, K. H., Bender, T. W., \& Joiner, T. E. (2008). Suicidal desire and the capability for suicide: Tests of the interpersonal-psychological theory of suicidal behavior among adults. Journal of Consulting and Clinical Psychology, 76(1), 72-83. https://doi.org/10.1037/0022-006X.76.1.72

Wibawarta, B. (2006). Bushido dalam masyarakat Jepang modern. Wacana, 8(1), 54-66.

Wirasto, R. T. (2012). Suicide prevention in Indonesia: Providing public advocacy. JMAJ, 55(1).

World Health Organization. (2019, September 2). Suicide. https://www.who.int/news-room/factsheets/detail/suicide

You, S., Van Orden, K. A., \& Conner, K. R. (2011). Social connections and suicidal thoughts and behavior. Psychology of Addictive Behaviors, 25(1), 180-184. https://doi.org/10.1037/a0020936 